\title{
Political Branding: A Consumer Perspective on Australian Political Parties
}

\author{
Martin Grimmer, University of Tasmania \\ Dennis C. Grube, University of Cambridge
}

\begin{abstract}
Why are voters in advanced democracies turning away from established mass parties to take their electoral chances elsewhere? This article draws on concepts from marketing scholarship, specifically branding and brand equity, to apply a 'consumer' lens that assesses the major parties in Australia as failing 'brands' being left behind by disillusioned voters. An initial sample of 200 voters were asked what words or phrases came to mind when they thought of each of four Australian federal political parties. The strength of associations for each party, elicited from this sample, was then validated on a broader sample of 1015 voters, in addition to whether the association was considered positive, neutral or negative. Data revealed distinct brand associations for each party, and the extent of penetration and brand equity across sub-groups of voters. We find that Australian mass parties are caught in a downward spiral of negative brand associations and low brand penetration, leading to voter dissatisfaction.
\end{abstract}

Keywords: political branding; mass parties; Australia.

There is now strong evidence across advanced democracies that established mass parties are in decline (Cross and Gauja, 2014; Whiteley, 2011), although effects are not uniform (Kölln, 2016). This is contributing to outcomes such as higher vote counts for some minority parties (e.g., Borisyuk et al., 2007; Cutts and Goodwin, 2014; Hartcher, 2016), a turn towards 'populist' parties (Bowler et al., 2017), or to populist capture of existing mass parties through 'outsider' leaders such as Donald Trump and Jeremy Corbyn (Diamond, 2016). In a social media age, such minority parties and outsider leaders have been able to fashion ever more direct connections with voters that circumvent the filtering effects of traditional media. But why are voters turning away from established parties and 'traditional' leaders to take their chances elsewhere? We approach this puzzle by drawing on concepts from marketing scholarship to apply a 'consumer' lens that assesses established mass parties as failing 'brands' being left behind by disillusioned voters. We examine the Australian case to establish what voters think their political parties stand for and what is revealed about why established mass parties may be finding themselves out of favour.

Our empirical focus is on two research questions: 
1. What are the 'brand attributes' that voters associate with Australian political parties, and their strength and favourability?

2. To what extent do these attributes vary by voters' own political preferences?

Utilising a mixed methods approach through a two-stage survey, we examine these questions for Australia's two major parties - the Australian Labor Party and the Liberal Party of Australia - and for two long-established minor parties - the National Party of Australia and the Australian Greens. We find that whilst minor parties enjoy a higher brand equity and greater brand penetration, this does not necessarily translate into a wider electoral appeal. For the major parties, we find lower levels of brand equity, and overwhelmingly negative brand associations in the minds of most voters. We argue that mass parties are caught between having to carve out a broad appeal - to be all things to all people - whilst still maintaining perceptions of their trust and authenticity when they are unable to deliver on the full breadth of their promises. In other words, we suggest that mass parties in the Australian context may have no choice but to accept a low brand equity to cast as wide a net as possible, only to find that the brand perceptions that follow are increasingly negative ones in the eyes of the public. As we note later in the discussion section, further research is needed in other jurisdictions to test this claim more widely, and to establish whether such negative brand perceptions can be mitigated by charismatic leaders able to superimpose their own positive brand over that of their party. In the sections that follow, we review key arguments from the political branding literature, before explaining the structure of the current study and the methods adopted. In analysing the data, we draw out the existing brand associations, whilst also outlining possible future directions for research.

\section{Political Branding}

The literature on political branding has developed its own distinct trajectory as a subfield of political marketing over the course of the last two decades. Scholars such as Scammell (2015) and Needham (2005) have sought to position 'the brand' as the conceptual tool that can best capture both the tangible and intangible components that work together to construct the reputation and 
image of political leaders and of parties (see also Lees-Marshment 2014: 103). For them, studying brands allows for the simultaneous analysis of '...the rational and apparently irrational, the hard and soft elements of voter choice, the big dimensions of political reputation and the seemingly trivial details of appearance and tone of voice' (Scammell, 2015: 7). Time also emerges as an important factor, with the literature emphasising that a brand cannot be built through a one-off transaction alone (Cosgrove, 2012: 107), and instead needs to be nurtured over time through a relationship marketing approach (Needham, 2005).

In a branding sense, political parties and politicians can be conceptualised of as offering products - an 'amalgam of policy, leader image, inherited memory, promise ...' (O'Shaughnessy, 2001: 1048) - or services - the 'promise of [what is] to be delivered in the future' which is 'sold on trust' (Nielsen and Larsen, 2014: 154). Pich et al. (2016: 103) further reinforce the services perspective of a political brand, arguing that the act of governing is 'intangible, complex and heavily reliant on people'. This view of a political brand as an amalgam of factors - and indeed, as an 'overall packaged concept' that can't easily be unbundled (Lock and Harris, 1996) - also makes it clear that perceptions of a party leader are closely intertwined with perceptions of a party as a whole, and of local candidates. This means that in studying party brands we are in fact studying a composite of contributing variables. In this regard, while leadership can be crucial to how a political party brand is perceived, as our results will show, it is but one element of the brand tableau (Pich et al., 2016; Scammell, 1995). As political branding scholars have also noted, the rise of 'message simplicity' (see Marland et al., 2017: 136-137) means that ever less complex formulations are being used to frame this composite collection of factors, thus also facilitating message control. As we discuss later, the Liberal Party's 'stop the boats' mantra in Australia is an excellent example.

Creating a strong brand offers parties the opportunity to package their political products into an easily digestible shorthand form (Needham, 2005), thus creating the message simplicity mentioned above. Brands also have the potential to instill in a political product or service a symbolic value which may enhance voter loyalty and attachment (Pich et al., 2016). As stated above, a brand is 
typically thought of as an intangible concept (Downer, 2016; MacDonald et al., 2015), but may be represented as 'a name, term, sign, symbol or design, or a combination of these, intended to identify the goods or services of one seller or group of sellers' (Kotler et al., 2005: 549). A brand is regarded as a source of competitive advantage and differentiation, and applied to politics may be used to differentiate one party's 'product' from that of its rivals thus leading, in theory, to greater electoral performance (French and Smith, 2010; Nielsen and Larsen, 2014). This will be particularly the case if a political party enjoys a favourable level of 'brand equity', a term used to refer to the overall value of a brand (Downer, 2016; French and Smith, 2010; Quester et al., 2014). Following this argument, the stronger the political brand equity, the more the brand will be recognisable to voters as a point of differentiation for the party. A brand, in this regard, becomes a heuristic in the minds of voters what Butler and Powell (2014: 494) term an 'informational short cut' - which makes the voting decision easier and less complicated when confronted with 'complex bundles of alternatives' (Nielsen and Larsen, 2014: 154). French and Smith's (2010) observation is particularly salutatory here that while many citizens have a low level of involvement with party politics, they are still likely to use heuristics when making voting decisions. This may especially be the case in times of uncertainty and doubt (Green, 2016).

Butler and Powell (2014) hark back to Stokes (1963) to outline the two components of a political party's brand that can influence not just the voting behaviour of electors, but also the voting decisions of elected members within the legislature as they consider different pieces of legislation. The two components include first, the role of a brand in encapsulating a party's ideological positioning, and second, its valence, capturing the ways in which the non-ideological components of a brand influence both voters and party members. Brand valence can also interact with ideological positioning. This has been noted previously in the U.S. (e.g., Cox and McCubbins, 2005), but is also very pertinent for Australian politics. For example, the consistent leadership in-fighting in the Australian Labor Party Government 2010-2013 established questions of 'leadership’ as a core brand association in a way that may have damaged the brand equity of the party by undermining its 
valence. At the same time, the leadership questions were fought through the lens of arguments about particular ideologically-based policy positions, such as what to do about the number of asylum seekers entering Australia by boat.

In this study, we adopt a consumer-oriented rather than a management-oriented approach to examining political brand equity (Marland and Flanagan, 2013; Nielsen and Larsen, 2014). As Johns and Brandenburg (2014: 90) note, there is a relative dearth of political marketing research focussing on voters, with most studies examining the perspectives of 'sellers rather than buyers in the market for votes'. In a management-oriented approach, political branding is examined from a strategic marketing perspective, with the application of concepts such as marketing orientation or brand orientation to the activities of political parties, as well as a focus on how an integrated brand infrastructure can assist in such things as message control for a party and its representatives (e.g., O'Shaughnessy et al., 2012). With a consumer-oriented perspective, brands and branding are examined by looking at consumer/voter learning (French and Smith, 2010), or in other words, how various brand associations are formed about a political party in the mind of the voter. From this point of view, brands are represented in memory as 'associative networks', with a 'central note' signifying the name of the brand and a number of other features that have become associated, via learning, with this central note (Nielsen and Larsen, 2014: 155).

French and Smith (2010) similarly apply the term 'knowledge structures' which surround an object (e.g., a political party) and are retrievable from memory as related nodes of information. Following French and Smith's (2010) explication, the Liberal Party of Australia is an information node (or central note) to which other nodes might be associated, such as current leader Malcolm Turnbull or former leader Tony Abbott (each with their own associations), the term 'stop the boats', the economy, conservatism, and so forth. Other associations subsequently span out from these. Brand associations are most likely to be the result of low-involvement cognitive learning, developed through a process of iconic rote learning (e.g., associating words/slogan/phrases with parties), though in some circumstances high involvement learning may occur through more complex 
reasoning processes (e.g., analysing and considering political party information in order to structure associations and concepts) (Quester et al., 2014). That said, brand associations are not typically the result of systematic information search (O'Cass, 2002). As such, the 'brand voter' is open to changes in public sentiment, trends and shifts in political momentum (Nielsen and Larsen, 2014), and the brand associations they adopt are not necessarily going to be consistent with the image promulgated by the given political party.

\section{The Current Study}

From a consumer point of view, brand equity can be measured in a number of ways, including brand awareness, loyalty, perceived quality, as well as by brand associations, which is the focus of the current research (French and Smith, 2010). Keller (1993) noted that brand associations may have strength (number of associations), favourability (positivity/negativity of associations) and uniqueness (distinctiveness of associations). To this list can be added brand penetration, which in a political branding sense refers to the reach and depth of a brand association across different subsets of voters (Ehrenberg and Goodhardt, 2002). French and Smith (2010) undertook brand concept mapping for the two main political parties in the UK: Conservative and Labour. In their methodology, respondents chose to rate the party they felt greatest affinity with; that is, only Conservative voters rated the Conservative party and so forth.

In order to assess brand equity across the four main federal political parties in Australia, we adopt a different approach by considering how political party brands are viewed by all voters regardless of their pre-established party loyalties - in order to assess how far a political party brand association may have reached across the electorate. One of the critiques of the current state of political branding research is that it hones in on elections and their lead-up, potentially creating a distorted view of voters' brand perceptions based on saturation election coverage. As Schneider and Ferie (2015: 65) assert: 'limiting empirical research on political brands to electoral races ignores the importance of brands as essential facilitators of the continuous party-voter relationship, which does not cease in between elections'. We address this concern by capturing the perceptions of Australian 
voters about party brands two years into a normal three-year Australian electoral cycle. Whilst this does not entirely exclude electoral effects on brand perceptions, it does enable us to examine which aspects of Australian party brands loom the largest in voter consciousness outside of the focussing environment of an election. As Needham (2005: 356-7) notes, the 'challenge for an incumbent is to provide post-purchase reassurance, and maintain their winning coalition of voters until the next opportunity for a sale.' She suggests that this requires a relationship marketing approach that builds reassurance over time, rather than the transactional 'sale' of policies that occurs at election time.

Australia operates as a federation, with one national/federal parliament, and state and territory-based parliaments in the various regions. The federal parliament is bi-cameral, with a UK style lower house populated from single-member electorates, and a US style Senate made up of elected senators from each state or territory. At both a federal and state level, as mentioned earlier, the two major parties are the Australian Labor Party and the Liberal Party of Australia, whilst the Australian Greens and the country-based National Party of Australia have minority representation. The nature of this federal system means that party brands may be different at state and national levels, and there may be cross-pollution of positive and negative associations in the minds of voters who might be satisfied with a party at a state level but not nationally, or vice versa. To counteract this cross-pollution as much as possible, our survey instruments focussed specifically on the federal iterations of each party. As we outline below, this study adopts a two stage qualitative and quantitative research approach to elicit brand associations for Australian political parties, and then test the equity of those associations across the electorate.

In addition, the survey was administered two-years into the term of the conservative Coalition government, ${ }^{1}$ which had campaigned hard on tightening immigration as a central part of the platform it took to the 2013 election. The slogan 'stop the boats' had been a ubiquituous part of the

\footnotetext{
${ }^{1}$ In Australia, the Liberal Party and the National Party operate under a coalition arrangement, whereby they maintain separate identities but govern together - leading them to be termed the 'Coalition' in general political parlance. Where the article refers to 'Coalition voters' it means the composite of voters who support the Liberal Party and the National Party.
} 
Coalition's electoral message and, as we outline below, it continued to show up as the single strongest brand association for the Liberal Party in the survey responses even two years after the election. Equally, prior to the 2013 election there had been consistent in-fighting for the leadership within the Labor government between Julia Gillard and Kevin Rudd, and this also loomed large in the responses.

\section{METHOD}

\section{Sample Frame and Characteristics}

Data were collected via online surveys through an Australian commercial research panel provider in October-November, 2015. Participants were matched to the broader Australian population in terms of age and gender and spread across Australian states and territories. An initial elicitation sample of 200 participants was surveyed to generate lists of associations for the four federal political parties mentioned above. A second, different validation sample of 1015 participants was subsequently surveyed to test the strength and favourability of the associations developed by the elicitation sample. To be included in the study, participants had to respond 'yes' to the question: 'are you eligible to vote in Australian Federal Elections?' Table 1 provides a summary of sample characteristics for the larger validation sample, including their voting intentions.

\section{Insert Table 1 about here}

\section{Survey Instruments and Procedure}

Stage one of the research involved a qualitative online survey to elicit brand associations for each of the four political parties. At the beginning of the survey, an introductory statement explained the nature of the study and emphasised that all responses were anonymous. After some demographic questions, participants were asked the following open-ended question for each party: 'What words, phrases or associations come to mind when you think of the (political party)?' Participants were encouraged to write as many associations as they wished. The order of presentation of the political parties was randomised to minimize the impact of item-context effects 
(Feldman and Lynch, 1988). Counterbalancing of items, along with anonymity, are also suggested by Podsakoff et al. (2003) as procedural remedies to control for common method bias. Participants were then asked the question: 'If a Federal election was held tomorrow, which political party would you be most likely to vote for; that is, which party would you give your primary vote to?' The order of presentation of the political parties (as well as an 'other' category) was also randomised.

Stage two of the research, which occurred one month after stage one, involved a quantitative online survey, aimed at validating the brand associations collected in stage one. For each party, a list of associations mentioned at least twice by the elicitation sample was developed. Again, the order of presentation of the political parties was randomised, as was the order of the associations for each party. For each of the associations, two closed-ended questions were asked: 'To what extent do you associate the following words or phrases with the (political party)? (1-5 scale from 'never' to 'always'), and 'Do you think the word or phrase is (negative, neutral, positive)?' As with stage one, the stage two survey included an introductory statement on the nature of the study that also assured anonymity of response, and demographic questions were asked. Participants were also asked to which party they would give their primary vote, with the order of presentation of the parties randomised. Finally, a range of questions on voter engagement were asked, which are beyond the scope of this paper.

Both online surveys were piloted on a convenience sample of 10 Australian voters in order to gauge intelligibility and to assess the time taken for completion. As a result of this, changes were made to the response scale for the strength of associations in the stage two survey so as to provide a more logical response format. Aside from this refinement, the survey was completed as intended and the layout was determined to be suitable and easy to follow. No feedback was received from any of the actual participants post-administration that indicated any problems with the surveys. The relevant survey questions are provided as an Appendix to this article. 


\section{RESULTS AND DISCUSSION}

\section{Stage One - Elicitation Data}

As stated above, the aim of the elicitation stage of the research was to develop lists of brand associations for each of the four federal political parties under study. This resulted in lists of 23 associations that were mentioned at least twice by respondents for the Labor Party, 26 for the Liberal Party, 15 for the National Party, and 30 for the Greens. Only four associations were mentioned for more than one party - conservative (Liberal and National), infighting (Labor and Liberal), left wing and progressive (Labor and Greens) - indicating a high degree of brand uniqueness. The associations for each party, and the number of times they were mentioned, can be seen in Table 2. As Table 2 shows, there are already some associations which stand out: good for business, conservative and right wing for the Liberal Party; unions, supports workers and large spenders for Labor; protecting the environment (very prominently), green and social justice for the Greens, and a country party, supports farmers and junior partner to the Liberals for the National Party.

\section{Insert Table 2 about here}

\section{Stage Two - Validation Data}

In order to validate the associations found in the elicitation phase, as discussed earlier, the associations for each party mentioned at least twice were tested on a larger, different sample of voters. Participants were asked to rate each association in terms of the extent to which they thought it represented the party, as well as the favourability of the association.

To gain an initial understanding of how the various brand associations within each party related to one another, data were subjected to multi-dimensional scaling (MDS) analysis using Proxscal in SPSS. MDS is a multivariate procedure, akin to Factor Analysis, which uses proximities/distances between objects in a dataset to determine the underlying, or 'hidden', structure (Kruskall and Wish, 1978). In our case, the 'objects' are the brand associations for each political party, for which MDS uses a measure of Euclidian distance to provide a visual map or plot of 
their interrelationships. The closer the objects, the stronger the relationship between them; the further apart, the weaker the relationship. For the current data, two-dimensional plots were used. This was to aid in presentation and interpretability (see Kruskall and Wish, 1978, for a discussion of considerations in deciding the level of dimensionality). Moreover, in each case, stress testing revealed scores in the acceptable range of 0.05 to 0.1 for each solution, with Scree plots showing that using three or more dimensions would not have meaningfully improved the level of stress in the data. The MDS maps of the brand associations for each political party are shown in Figures 1-4.

\section{Insert Figures 1-4 about here}

These figures reveal both clusters of brand associations for each party, as well as how individual associations are related to others. In Figure 1 for the Liberal Party, it is possible to discern clusters associated with economic management on the right of the figure (e.g., balance the budget, economic growth), wealth and big business on the left (e.g., rich, pro big business), as well as a series of specifically negative associations (e.g., not compassionate, liars, untrustworthy) on the lower left. It is also noteworthy that the association closest to the word Liberal is stop the boats, indicating the strength of this brand attribute for the Liberal Party. For the Labor Party in Figure 2, there are clusters concerning workers' and general rights on the right (e.g., working conditions, social conscience, for people), unionism and infighting on the lower left (e.g., union dominated, factions), and incompetence and corruption on the left (e.g., dishonest, incompetent). Unions as an association can also be seen to be quite distant from socialist and closer to both working class and infighting, suggesting that voters don't link unionism with its ideological roots, but rather with more contemporary connotations.

In Figure 3 for the Greens, there is a large cluster of negative associations on the right of the plot which encompasses both structural (e.g., leadership vacuum, antibusiness, un-Australian) and more specifically disparaging (e.g., hippies, loonies/idiots, naïve) elements. On the left of the figure are a range of positive associations, which include clusters specifically on the environment and 
climate (e.g., trees/forests, protecting the environment), and on more general policy standpoints (e.g., social justice, sustainability). Intimating a clear brand identity, the word green appears in the environment cluster, closest to trees/forests. For the Nationals in Figure 4, noting the smaller overall number of associations as mentioned above, there is a cluster on the lower right which encompasses a group of positive values (e.g., hardworking, caring), a cluster to the left of this that relates to the party's rural base (e.g., supports farmers, rural), and two broader groupings to the top of the plot regarding the political leaning of the party (e.g., conservative, junior partner to the Liberals), and its negative links (e.g. old-fashioned, rednecks, small). There does appear to be evidence of an understood identity in the fact that The Nationals, as an association, is closest to the rural-based cluster (accepting, however, that The Nats, a shorthand association for the party, is within the political leaning grouping).

The MDS plots provide an understanding of how the various party associations are linked in the minds of the participants, that is, their 'associative networks' (Nielsen and Larsen, 2014) or 'knowledge structures' (French and Smith, 2010). The plots thus allow for the evaluation of distinct clusters of brand attributes. The next stage is to assess their strength and favourability. Tables 3-6 show the top 10 associations for each of the four federal political parties, as well as the level of favourability of these associations (red=negative (1); black=neutral (2); green=positive (3)). In order to assess if an association was neutral, a range of $+/-0.1$ around the centred neutral rating of 2 was arbitrarily chosen. Outside of this range, an association was judged as either negative or positive. The mean level of association for each party was also determined (based on the 1-5 scale from 'never' to 'always'), which is shown on the Tables. Analysis of Variance (ANOVA) indicated no significant difference across the four parties $(F(3,88)=1.34, p>0.05)$. Notwithstanding this result, as already indicated, there were differences in terms of the number of associations elicited for each party, with the Greens (at 30) having the most, and the Nationals (at 15) having the least.

Insert Tables 3-6 about here 
The information provided in Tables 3-6 permits an examination of the favourability of the brand associations for each party and their penetration across sub-groups of voters. To begin with the Liberal Party, there is one overall highly-rated positive association - Liberal - and six overall negative associations - pro big business, looking after the rich, rich, high end of town, right wing, arrogant. Stop the boats is the highest overall association (in this case a neutral one), despite it being only mentioned by three participants in the elicitation sample. There are also significant differences across different voter groups. Due to there only being $4.6 \%$ of the validation sample who indicated they would vote for the National Party, this subset was collapsed into the Liberal Party subset to create a single group of Coalition voters. Perhaps not surprisingly, all of the associations amongst Coalition voters are positive; in addition, they differ greatly from the other voters in content. For example, these are the only voters to rate highly associations around economic management and being good for business. In comparison, all of the associations with the Liberal Party are negative for Labor and Green voters, with only one positive for Independent/other voters: stop the boats. No associations are mentioned by every voting group, with eight associations mentioned by three voting groups, all but one (again, stop the boats) being negative associations. This paints a picture of low favourability for the Liberal party, and low-moderate penetration.

For the Labor Party, there are three overall highly-rated positive associations - working class, working conditions, supports workers - and seven overall negative associations - unions, uniondominated, large spenders, infighting, factions, poor leadership, debt creators. The highly-rated associations for Labor also accord with the elicitation sample data. Turning to the different voter groups, there appears to be some commonality between Coalition and Independent voters, and between Labor and Green voters; in the latter case, there are positives mentioned by both groups. However, only the Labor voters have all positive associations rated highly. Negative associations appear to have the greater reach across the voting groups. One association is mentioned by every voting group - unions (only positive for Labor voters) - with four associations mentioned by three 
voting groups, all being negative associations. This reveals an impression of low-moderate favourability for the Labor party, and low-moderate penetration.

The Australian Greens have six overall highly-rated positive associations - green, trees/forests, climate, protecting the environment, supporting same-sex issues, sustainability - and one overall negative association - minor party. As with Labor, the Greens' highly-rated associations accord with the elicitation sample data. For the Greens, there seems to be more commonality across all voting groups, both in terms of content and favourability. For example, all but one of the high associations for the Greens are positive for Labor voters, and all for Greens voters. There are five associations mentioned by every voting group - largely similar to the overall positive list - with a further one association mentioned by three voting groups. This suggests moderate-high favourability for the Australian Greens, and high penetration.

Finally, the Nationals have four overall highly-rated positive associations - the Nationals, rural, a country party, supports farmers - and three overall negative associations - junior partner to the Liberals, old-fashioned, small. The Nationals' highly-rated associations also accord with the elicitation sample data. There appears to be a lot of commonality of content across the different voter groups, but less in terms of the level of favourability; Coalition voters have all positive associations in their top 10, but the other voting groups, on balance, have more negative associations. There are seven associations mentioned by every voting group - largely similar to the overall positive list with three additions: Coalition, conservative, junior partner to the Liberals - and a further two associations mentioned by three voting groups. This suggests moderate favourability for the National Party, and high penetration.

On the basis of our results, the party with the highest level of brand equity is the Australian Greens, and the party with the lowest is the Liberal Party of Australia.

\section{GENERAL DISCUSSION}


The aim of this research was to investigate the 'brand attributes' that voters associate with four Australian political parties, and the extent of penetration across voter subgroups. By applying the marketing concept of branding, the intention was to shed new light on the party associations that have embedded themselves sufficiently into the consciousness of Australian voters as to now be synonymous with the parties themselves. Our research suggests that the brands of Australian political parties reflect both contemporary and historical factors. The historical factors seem to harden over time into brand associations in voters' minds that are hard to change based on contemporary debates. For the major parties in particular, this can have both positive and negative effects. For example, the association of the Labor Party brand with workers and worker's rights appears deeply ingrained, but this co-exists with related negative perceptions about the power of unions within the party. Similarly, the Liberal Party brand is strongly associated with sound economic management (at least for Coalition voters), but is balanced by an equally deep impression that the party supports the 'top end of town.' This means that when either party seeks to go outside its positive brand associations to counteract negative views it is facing deeply ingrained perceptions about what the party stands for (Cox and McCubbins, 2005).

These deeply embedded historical aspects co-exist as brand associations in the minds of voters with the more contemporary political and policy issues of the day. For example, 'stop the boats' was revealed as the number one brand association for the Liberal Party, based on their contemporary policy position on how to respond to asylum seekers trying to reach Australian shores by boat. Similarly, 'infighting' and 'poor leadership' emerged as key brand attributes for the Labor Party based on recent political events that clearly loomed large in the minds of voters responding to the survey. This suggests that at the point the survey was administered, the Liberal Party had more successfully exercised message control to maintain the kind of cohesive 'high-level partisan brand' that Cosgrove (2012) associates with the Reagan era Republican Party in the USA, and the Harper Government in Canada. 
Perhaps because of their need to appeal to the widest possible cross-section of voters in order to be able to form government, the major parties had lower brand equity than a party such as the Greens. Whilst the leaders of the Greens seek to assert that the values and policies of the party extend far beyond caring for the environment, this remains the overriding brand association amongst voters from across the political spectrum. This gives them a high brand equity, but one grounded in a narrow perception of their policy focus. Our data suggest that the electoral benefits of having a high level of brand equity are not necessarily immediately apparent, despite an assumption that brand equity leads to performance (Aaker, 2009). Further study is needed to investigate the extent to which high brand equity translates into positive voting choices that might not occur if the brand equity was lower. There is clearly a complicated relationship between brand equity and party performance, and as Downer (2016) argues, not enough emphasis is placed on voter-percevied equity and how to harness it.

The scale of the task facing the major parties is particularly highlighted by the fact that the majority of their existing brand associations are seen as negative by our sample of voters as a whole - and it is a negativity from which it is not easy to escape. Independent voters in particular, view the brand attributes of both major parties as almost entirely negative. These potentially damaging associations are consistently targeted by the political marketing campaigns of the parties themselves at election time, as each tries to activate negative associations of the other in voters' minds. Evidence from the literature on negative political advertising shows that this kind of focus can be especially effective with voters who have an otherwise low level of involvement in politics (Geer, 2006; Jackson, Mondak and Huckfeldt, 2009; Stone et al., 2013).

These data suggest that major parties are to some extent caught in a negativity trap as they seek to sharpen and define their party brands. As parties who hope to form government, they need to be able to generate a wide brand appeal. In other words, they need to spread their brand across the widest possible playing field, which in the process dilutes the focus on core attributes. At the 
same time, as parties of government, they carry the electoral baggage of having actually made hard or unpopular decisions that can bleed over into the party brand in a way that clearly doesn't apply to minor parties. What results for both Labor and Liberal is a type of brand image that is dominated by negative associations. In contrast, whilst the Greens and to a lesser extent the National Party enjoy greater brand equity, and more positive associations, this does not translate into wider electoral popularity. They remain shackled to their core ideological brand associations, unable to translate those positive attributes into a wider set of brand associations capable of propelling them into contention as parties of government in their own right (notwithstanding the important role of the Nationals in Coalition governments with the Liberal Party).

If established minor parties are proving unable to translate their strong brand equity into a higher share of votes, then to whom are disillusioned voters turning? Certainly in the Australian case, the answer seems to be to newer 'populist' alternatives. The results from the last two Australian elections saw strong outcomes in 2013 for the Palmer United Party (a very new party centred on high-profile businessman Clive Palmer), and in 2016 for the One Nation Party (a party with a twentyyear history centred around the high-profile former lower-house MP, and now Senator, Pauline Hanson). Interesting work is already emerging on the recent performance of these parties (e.g., Kefford and McDonnell, 2016), and further research into the brand attributes of such consciously 'populist' minor parties could shed light on how newer parties are able to shape the brand associations that will define them over time.

If mass political parties are to continue as governing parties into the future, it is pertinent to ask whether they can in fact break out of their low brand equity/negativity spiral? Further research is needed on the extent to which choice of leader is a key variable. It is possible leaders might be able to superimpose their own personal brand on top of that of their party and in the process create a higher brand equity by relying on their personal popularity to popularise the wider party brand. For example, Cosgrove (2012) suggests that in the United States the positive Obama brand was able to 
eclipse the weaker and more dispersed Democratic Party brand. Arguably a leader such as Prime Minister Justin Trudeau in Canada is harnessing such an effect, and clearly the Liberal Party in Australia were searching for something similar when they replaced Tony Abbott as Prime Minister in 2015 with the then highly popular Malcolm Turnbull. In a sobering result for parties looking to the personal brand of a popular leader as a path to political salvation, our results (and subsequent polling in Australia) suggest that Turnbull's popularity did not translate across into more positive brand associations for his party. Indeed, Downer (2016) points out that there is a risk associated with parachuting in a new 'saviour' party leader who ultimately is not effective, with the tainted leader's brand subsequently threatening the party brand. This argument is supported by Davies and Mian (2010) who, in their study of leader and party reputations in British General Elections, found that such reputations are related but distinct, with the leader's reputation affecting the reputation of the party more than the reverse.

By focussing the research for this study two years into a normal three-year governing term, the data reveal just how deeply embedded the associations created during an election campaign remain in the minds of voters long after the campaign is over. For example, the Liberal Party ran very hard during the 2013 election campaign on their promise to 'stop the boats'. Our research shows that two years later, that remained the top brand association for the Liberal Party. More work is needed to analyse whether that association resulted from the election campaign, or whether it simply followed the focus of government policy at the time of the survey. The fact that two of the top Labor associations were around infighting and poor leadership suggest that voters have longer memories and brand associations have greater depth - than simply being an association formed at election time, and then forgotten. This supports Needham's (2005) argument that a relationship marketing perspective - which focusses on maintaining connection with a brand over time - is indeed central to the ability of a political party to persuade voters not to abandon them on election days. 
The findings of this study suggest some potentially fruitful areas for further research, as already indicated. First, further longitudinal research is needed to test whether recent Australian experience is typical, or whether our results reflect the fact that the particulary bitter partisanship of the past few years has translated more readily across into perceptions of party brands. Second, it is unclear from the data whether voters are making judgements about the authenticity of politicians who seek to draw on the positive brand attributes of their party. Some existing research suggests that brand authenticity is a key factor in its utility for swaying voters (Lees-Marshment, 2011), and more research is needed on this in the Australian setting. Third, the data from this study suggest that longer-term brand attributes can be so engrained that voters are deaf to attempts by parties to change them. So, do parties simply have to live within the confines of their existing brands, or are there realistic strategies for altering them?

\section{CONCLUSION}

Clearly, contemporary political behaviour and slogans do matter, and do translate into strong brand associations. Rather than replacing older associations, they operate in addition to longer established voter perceptions about the ideological positions and values of the party. Thus, Labor are still perceived as being associated with unions, and the Liberals as being close to big business - but these attributes are then joined by more contemporary judgements about leadership, or policies such as 'stop the boats'. A lesson from this research may be that the persistence and depth of the older associations, even if they are subsequently added to, explains why party change is so hard to achieve. What is less clear from these data is whether the contemporary associations - 'stop the boats'; 'infighting' - fall away over time to be replaced by other 'attributes of the moment'; or whether they can harden into more entrenched aspects of the brand. Either way, this study suggests that analysing voters as consumers of party 'brands' offers a promising lens for understanding the heuristics that are guiding voter behaviour when they step into the polling booth. 


\section{REFERENCES}

Aaker DA (2009) Managing Brand Equity. New York, Simon and Schuster.

Borisyuk G, Rallings C, Thrasher M and van der Kolk H (2007) Voter support for minor parties: assessing the social and political context of voting at the 2004 European elections in greater London. Party Politics 13(6): 669-693.

Bowler S, Denemark D, Donovan T and McDonnell D (2017) Right-wing populist party supporters: dissatisfied but not direct democrats. European Journal of Political Research 56(1): 70-91..

Butler DM and Powell EN (2014) Understanding the party brand: experimental evidence on the role of valence. The Journal of Politics 76(2): 492-505.

Cosgrove KM (2012) Political Branding in the Modern Age: Effective Strategies, Tools and Techniques. In Lees-Marshment J (ed) The Routledge Handbook of Political Marketing. London: Routledge, 107-123.

Cox G and McCubbins M (2005) Setting the Agenda: Responsible Party Government in the US House of Representatives. Cambridge: Cambridge University Press.

Cross W and Gauja A (2014) Evolving membership strategies in Australian political parties. Australian Journal of Political Science 49(4): 611-625.

Cutts D and Goodwin MJ (2014) Getting out the right-wing extremist vote: extreme right party support and campaign effects at a recent British general election. European Political Science Review 6(1): 93-114.

Davies $G$ and Mian T (2010) The reputation of the party leader and of the party being led. European Journal of Marketing 44(3/4): 331-350.

Diamond P (2016) Assessing the performance of UK opposition leaders: Jeremy Corbyn's straighttalking, honest politics. Politics and Governance 4(2): 15-24.

Downer L (2016) It's the equity stupid! Protecting the value of the partisan brand. Journal of Nonprofit \& Public Sector Marketing 28(1): 22-39.

Ehrenberg ASC and Goodhardt GJ (2002) Double jeopardy revisited, again. Marketing Research 14(1): 40-42.

Feldman JM and Lynch JG Jr (1988) Self-generated validity and other effects of measurement on belief, attitude, intention, and behavior. Journal of Applied Psychology 73: 421-435.

French A and Smith G (2010) Measuring political brand equity: a consumer oriented approach. European Journal of Marketing 44(3-4): 460-477.

Geer JG (2006) In Defence of Negativity. Chicago: University of Chicago Press. 
Green J (2016) The two-party duopoly became too clever by half. ABC News, July 6, 2016. Available at: http://www.abc.net.au/news/2016-07-05/green-the-two-party-duopoly-became-tooclever-by-half/7568888

Hartcher P (2016) A plague on both your houses: Fairfax Ipsos shows minor parties prospering. The Sydney Morning Herald, November 28, 2016. Available at: http://www.smh.com.au/federalpolitics/political-opinion/a-plague-on-both-your-houses-fairfax-ipsos-shows-minor-partiesprospering-20161127-gsynjt.html.

Jackson RA, Mondak JT and Huckfeldt R (2009) Examining the possible corrosive impact of negative advertising on citizens' attitudes toward politics. Political Research Quarterly 62(1): 55-69.

Johns R and Brandenburg H (2014) Giving voters what they want? Party orientation perceptions and preferences in the British electorate. Party Politics 20(1): 89-104.

Kefford G and McDonnell D (2016) Ballots and billions: Cliver Palmer's personal party. Australian Journal of Political Science 51(2): 183-197.

Keller KL (1993) Conceptualizing, measuring, and managing customer-based brand equity. Journal of Marketing 57(1): 1-22.

Kölln AK (2016) Party membership in europe: testing party-level explanations of decline. Party Politics 22(4): 465-477.

Kotler P, Wong V, Saunders J and Armstrong G (2005) Principles of Marketing, $4^{\text {th }}$ ed. Mateu-Cromo Artes Graficas, Spain: Pearson Education Limited.

Kruskall JB and Wish M (1978) Multidimensional Scaling. Beverly Hills: Sage Publications University Paper Series: Quantitative Applications in the Social Sciences.

Lees-Marshment J (2011) The Political Marketing Game. Basingstoke, Palgrave Macmillan.

Lees-Marshment J (2014) Political Marketing: Principles and Applications. London, Routledge.

Lock A and Harris P (1996) Political marketing - vive la difference! European Journal of Marketing 30(10/11): 21-31.

MacDonald EA, Sherlock R and Hogan J (2015) Measuring political brand equity in Ireland. Irish Political Studies 3(1): 98-120.

Marland A and Flanagan T (2013) Brand new party: political branding and the Conservative Party of Canada. Canadian Journal of Political Science 46(4): 951-972.

Marland A, Lewis JP and Flanagan T (2017) Governance in the age of digital media and branding. Governance 30(1): 125-141.

Needham C (2005) Brand Leaders: Clinton, Blair and the limitations of the permanent campaign. Political Studies 53: 343-361. 
Nielsen S G and Larsen MV (2014) Party brands and voting. Electoral Studies 33: 153-165.

O'Cass A (2002) A micromodel of voter choice: understanding the dynamics of Australian voter characteristics in a Federal election. Psychology \& Marketing 19(12): 1025-1046.

O'Shaughnessy N (2001) The marketing of political marketing. European Journal of Marketing 35(9/10): 1047-1057.

O'Shaughnessy NJ, Baines PR, O'Cass A and Ormrod RP (2012) Political marketing orientation: confusions, complications, and criticisms. Journal of Political Marketing 11(4): 353-366.

Pich C, Dean D and Punjaisri K (2016) Political brand identity: an examination of the complexities of Conservative brand and internal market engagement during the 2010 UK General Election campaign. Journal of Marketing Communications 22(1), 100-117.

Podsakoff PM, MacKenzie SB, Lee JY and Podsakoff NP (2003) Common method biases in behavioural research: a critical review of the literature and recommended remedies. Journal of Applied Psychology 88(5): 879-903.

Quester P, Pettigrew S, Kopanidis F and Rao Hill S (2014) Consumer Behaviour: Implications for Marketing Strategy, $7^{\text {th }}$ ed. Australia: McGraw-Hill Education.

Scammell M (1995) Designer Politics: How Elections Are Won. London: Macmillan.

Scammell, M (2015) Politics and Image: The Conceptual Value of Branding. Journal of Political Marketing 14(1-2): 7-18.

Schneider $\mathrm{H}$ and Ferié $\mathrm{F}$ (2015) How to manage a party brand: empirical perspectives on electoral probability and internal conflict. Journal of Political Marketing 14(1-2): 64-95.

Stokes DE (1963) Spatial models of party competition. American Political Science Review 57(2): 36877.

Stone GW, Blodgett JG, Nkonge J and Cort KT (2013) The moderating influence of political involvement on voters' attitudes toward attack ads. Journal of Marketing Theory and Practice 21(1): 91-101.

Whiteley PF (2011) Is the party over? the decline of party activism and membership across the democratic world. Party Politics 17(1): 21-44. 


\section{Appendix - Brand Association Survey Questions}

This appendix contains the relevant instructions and questions administered to participants in each stage of the study.

\section{Stage 1 - Elicitation of Brand Associations}

In this section, you will be asked some questions about your impressions of four Federal political parties. This survey has four main questions only. For each of the following questions, please take the time to think about your answers and provide as much detail as possible.

Please list below the words, phrases or associations that come to mind when you think of the (political party)? List as many as you can think of.

[This question was repeated for each of the four political parties studied]

If a Federal election was held tomorrow, which political party would you be most likely to vote for; that is, which party would you give your primary vote to:

1. Liberal Party of Australia

2. National Party of Australia

3. Australian Labor Party

4. Australian Greens

5. Other (please specify:)

\section{Stage 2 - Validation of Brand Associations}

In this section, you will be asked some questions about your impressions of four Federal political parties. You will be presented a list of words or phrases that were gathered from a sample of Australian voters to describe each political party. You will be asked to rate:

1. The extent to which you associate the word or phrase with the political party

2. Whether you think the word or phrase is negative, neutral or positive

For each word or phrase, please provide the response that first comes to mind for each question.

[Participants were then presented with tables of associations for each party, elicited in stage one of the study, with the following questions]

1. To what extent do you associate the following words or phrases with the (political party)?

1. Never Associate

2. Seldom Associate

3. Associate Some of the Time

4. Often Associate 


\section{Always Associate}

2. Do you think the word or phrase is:

1. Negative

2. Neutral

3. Positive

[The voting intention question was repeated here] 
Table 1. Validation Sample Characteristics.

\begin{tabular}{|c|c|c|c|}
\hline Age: mean $=47.96(S D=16.87)$ & & Gender: & \\
\hline $18-29$ years & $17.3 \%$ & Male & $49.7 \%$ \\
\hline 30-39 years & $17.8 \%$ & Female & $50.3 \%$ \\
\hline 40-49 years & $17.9 \%$ & \multirow{10}{*}{$\begin{array}{l}\text { State/Territory: } \\
\text { ACT } \\
\text { New South Wales } \\
\text { Northern Territory } \\
\text { Queensland } \\
\text { South Australia } \\
\text { Tasmania } \\
\text { Victoria } \\
\text { Western Australia }\end{array}$} & \\
\hline $50-59$ years & $17.6 \%$ & & $4.2 \%$ \\
\hline $60-69$ & $17.6 \%$ & & $19.5 \%$ \\
\hline 70 plus years & $11.9 \%$ & & $0.6 \%$ \\
\hline Education: & & & $19.6 \%$ \\
\hline No High School to Year 10 & $3.5 \%$ & & $19.1 \%$ \\
\hline High School to Year 10 & $12.6 \%$ & & $4.2 \%$ \\
\hline High School to Year 12 & $19.1 \%$ & & $19.8 \%$ \\
\hline $\begin{array}{l}\text { Trade Qual. or Apprent. or } \\
\text { TAFE Cert/Dip }\end{array}$ & $29.6 \%$ & & $12.8 \%$ \\
\hline Bachelor Degree (incl. hons) & $23.1 \%$ & & \\
\hline $\begin{array}{l}\text { Postgrad. Coursework } \\
\text { Cert/Dip/Degree }\end{array}$ & $8.1 \%$ & \multirow{7}{*}{$\begin{array}{l}\text { Marital Status: } \\
\qquad \begin{array}{l}\text { Single, never marr. } \\
\text { Married } \\
\text { De-facto } \\
\text { Separated, not div. } \\
\text { Divorced } \\
\text { Widowed } \\
\end{array}\end{array}$} & \\
\hline Research Masters or PhD & $4.1 \%$ & & $26.0 \%$ \\
\hline Voting Intention: & & & $48.9 \%$ \\
\hline Australian Greens & $12.2 \%$ & & $11.3 \%$ \\
\hline Australian Labor Party & $34.1 \%$ & & $1.9 \%$ \\
\hline Liberal Party of Australia & $34.0 \%$ & & $8.5 \%$ \\
\hline National Party of Australia & $4.6 \%$ & & $3.4 \%$ \\
\hline Other & $15.1 \%$ & $\begin{array}{c}\text { Children living at home? } \\
\text { Yes } \\
\text { No }\end{array}$ & $\begin{array}{l}34.5 \% \\
65.5 \%\end{array}$ \\
\hline
\end{tabular}


Table 2. Elicitation Sample Party Brand Associations (number of times mentioned).

\begin{tabular}{|c|c|c|c|}
\hline $\begin{array}{l}\text { Liberal Party of } \\
\text { Australia (26) }\end{array}$ & $\begin{array}{c}\text { Australian Labor } \\
\text { Party (23) }\end{array}$ & $\begin{array}{c}\text { Australian Greens } \\
\text { (30) }\end{array}$ & $\begin{array}{l}\text { National Party of } \\
\text { Australia (15) }\end{array}$ \\
\hline $\begin{array}{l}\text { Good for business } \\
\text { (21) }\end{array}$ & Unions (26) & $\begin{array}{l}\text { Protecting the } \\
\text { environment (49) }\end{array}$ & A country party (31) \\
\hline Conservative (20) & $\begin{array}{l}\text { Supports workers } \\
\text { (25) }\end{array}$ & Green (12) & $\begin{array}{l}\text { Supports farmers } \\
\text { (26) }\end{array}$ \\
\hline Right wing (17) & Large spenders (11) & Social justice (10) & $\begin{array}{l}\text { Junior partner to the } \\
\text { Liberals (24) }\end{array}$ \\
\hline $\begin{array}{l}\text { Economic } \\
\text { management (11) }\end{array}$ & $\begin{array}{l}\text { Supports } \\
\text { disadvantaged } \\
\text { people (8) }\end{array}$ & Left wing (8) & Not well known (20) \\
\hline $\begin{array}{l}\text { Looking after the } \\
\text { rich (11) }\end{array}$ & Union-dominated (8) & Climate (7) & Conservative (12) \\
\hline Rich (10) & Working class (8) & Loonies/idiots (7) & Rural (10) \\
\hline High end of town (8) & For the people (7) & Uncompromising (7) & Coalition (7) \\
\hline Liars (8) & Incompetent (7) & Fair (6) & Old-fashioned (5) \\
\hline Liberal (8) & Debt creators (6) & Future-focussed (6) & Small (4) \\
\hline Pro big business ( 8 ) & Disorganised (6) & Hippies (6) & The Nationals (4) \\
\hline Business savvy (7) & Infighting (6) & Linked with Labor (6) & Honest (3) \\
\hline $\begin{array}{l}\text { Not compassionate } \\
\text { (7) }\end{array}$ & Left wing (6) & Sustainability (6) & Rednecks (3) \\
\hline Arrogant (5) & Poor leadership (6) & Trees/forests (6) & Caring (2) \\
\hline $\begin{array}{l}\text { Balance the budget } \\
\text { (5) }\end{array}$ & Factions (5) & Useless (6) & Hard-working (2) \\
\hline Consistent (4) & Progressive (5) & Idealistic (5) & 'The Nats' (2) \\
\hline Infighting (4) & Corrupt (4) & Liberal (small 'l') (5) & \\
\hline Out of touch (4) & Fairness (4) & Minor party (5) & \\
\hline Untrustworthy (4) & Social conscience (4) & Natural (5) & \\
\hline Economic growth (3) & $\begin{array}{l}\text { Working conditions } \\
\text { (4) }\end{array}$ & Unrealistic (5) & \\
\hline Good managers (3) & Dishonest (3) & Alternative (4) & \\
\hline Stop the boats ( 3 ) & Socialist (3) & Greenies (4) & \\
\hline Traditional (3) & $\operatorname{Red}(2)$ & $\begin{array}{l}\text { Leadership vacuum } \\
\text { (4) }\end{array}$ & \\
\hline Powerful (2) & Solid (2) & Naïve (4) & \\
\hline Selfish (2) & & Refugees (4) & \\
\hline Smart (2) & & Anti-business (3) & \\
\hline \multirow[t]{5}{*}{ Trustworthy (2) } & & Progressive (3) & \\
\hline & & $\begin{array}{l}\text { Supporting same-sex } \\
\text { issues (3) }\end{array}$ & \\
\hline & & Weak (3) & \\
\hline & & Bludgers (2) & \\
\hline & & Un-Australian (2) & \\
\hline
\end{tabular}


Table 3. Top 10 Voter Associations - Liberal Party of Australia (out of 26; $\bar{x}=3.34$ )

\begin{tabular}{|c|l|l|l|l|l|}
\hline & Overall & $\begin{array}{l}\text { Coalition } \\
\text { Voters }\end{array}$ & Labor Voters & Green Voters & $\begin{array}{l}\text { Independent } \\
\text { Voters }\end{array}$ \\
\hline $\mathbf{1}$ & $\begin{array}{l}\text { Stop the } \\
\text { boats }\end{array}$ & Stop the boats & $\begin{array}{l}\text { Looking after } \\
\text { the rich }\end{array}$ & Arrogant & $\begin{array}{l}\text { Looking after } \\
\text { the rich }\end{array}$ \\
\hline $\mathbf{2}$ & $\begin{array}{l}\text { Pro big } \\
\text { business }\end{array}$ & Liberal & Rich & $\begin{array}{l}\text { Looking after } \\
\text { the rich }\end{array}$ & $\begin{array}{l}\text { Pro big } \\
\text { business }\end{array}$ \\
\hline $\mathbf{3}$ & $\begin{array}{l}\text { Looking after } \\
\text { the rich }\end{array}$ & $\begin{array}{l}\text { Economic } \\
\text { management }\end{array}$ & Arrogant & Pro big business & Arrogant \\
\hline $\mathbf{5}$ & $\begin{array}{l}\text { Liberal } \\
\text { business }\end{array}$ & $\begin{array}{l}\text { Economic } \\
\text { growth }\end{array}$ & $\begin{array}{l}\text { High end of } \\
\text { town }\end{array}$ & $\begin{array}{l}\text { Selfish } \\
\text { bompassionate }\end{array}$ & Selfish \\
\hline $\mathbf{6}$ & $\begin{array}{l}\text { High end of } \\
\text { town }\end{array}$ & $\begin{array}{l}\text { Business } \\
\text { savvy }\end{array}$ & Out of touch & Right wing & Liars \\
\hline $\mathbf{7}$ & Conservative & $\begin{array}{l}\text { Balance the } \\
\text { budget }\end{array}$ & Selfish & Liars & $\begin{array}{l}\text { High end of } \\
\text { town }\end{array}$ \\
\hline $\mathbf{8}$ & Right wing & $\begin{array}{l}\text { Good } \\
\text { managers }\end{array}$ & Liars & Untrustworthy & Out of touch \\
\hline $\mathbf{9}$ & Powerful & Powerful & Untrustworthy & Out of touch & Untrustworthy \\
\hline 10 & Arrogant & Conservative & Stop the boats & Conservative & Stop the boats \\
\hline
\end{tabular}

Note: red = negative; black = neutral; green = positive . 
Table 4. Top 10 Voter Associations - Australian Labor Party (out of 23; $\bar{x}=3.25$ )

\begin{tabular}{|c|c|c|c|c|c|}
\hline & Overall & $\begin{array}{l}\text { Coalition } \\
\text { Voters }\end{array}$ & Labor Voters & Green Voters & $\begin{array}{l}\text { Independent } \\
\text { Voters }\end{array}$ \\
\hline 1 & Unions & Unions & $\begin{array}{l}\text { Supports } \\
\text { workers }\end{array}$ & Unions & Unions \\
\hline 2 & $\begin{array}{l}\text { Union- } \\
\text { dominated }\end{array}$ & $\begin{array}{l}\text { Union- } \\
\text { dominated }\end{array}$ & Working class & $\begin{array}{l}\text { Working } \\
\text { conditions }\end{array}$ & Large spenders \\
\hline 3 & $\begin{array}{l}\text { Working } \\
\text { class }\end{array}$ & $\begin{array}{l}\text { Large } \\
\text { spenders }\end{array}$ & For the people & Working class & $\begin{array}{l}\text { Union- } \\
\text { dominated }\end{array}$ \\
\hline 4 & $\begin{array}{l}\text { Large } \\
\text { spenders }\end{array}$ & Debt creators & $\begin{array}{l}\text { Working } \\
\text { conditions }\end{array}$ & $\begin{array}{l}\text { Supports } \\
\text { workers }\end{array}$ & $\begin{array}{l}\text { Poor } \\
\text { leadership }\end{array}$ \\
\hline 5 & Infighting & $\begin{array}{l}\text { Poor } \\
\text { leadership }\end{array}$ & Unions & Poor leadership & Infighting \\
\hline 6 & $\begin{array}{l}\text { Working } \\
\text { conditions }\end{array}$ & Factions & $\begin{array}{l}\text { Support } \\
\text { disadvantaged } \\
\text { people }\end{array}$ & Infighting & Factions \\
\hline 7 & Factions & Infighting & $\begin{array}{l}\text { Social } \\
\text { conscience }\end{array}$ & $\begin{array}{l}\text { Union- } \\
\text { dominated }\end{array}$ & Incompetent \\
\hline 8 & $\begin{array}{l}\text { Supports } \\
\text { workers }\end{array}$ & Disorganised & Fairness & $\begin{array}{l}\text { Support } \\
\text { disadvantaged } \\
\text { people }\end{array}$ & Dishonest \\
\hline 9 & $\begin{array}{l}\text { Poor } \\
\text { leadership }\end{array}$ & Incompetent & Progressive & For the people & Disorganised \\
\hline 10 & $\begin{array}{l}\text { Debt } \\
\text { creators }\end{array}$ & Left wing & Solid & Factions & Debt creators \\
\hline
\end{tabular}

Note: red = negative; black = neutral; green = positive . 
Table 5. Top 10 Voter Associations - Australian Greens (out of 30; $\bar{x}=3.14$ )

\begin{tabular}{|c|c|c|c|c|c|}
\hline & Overall & $\begin{array}{l}\text { Coalition } \\
\text { Voters }\end{array}$ & Labor Voters & Green Voters & $\begin{array}{l}\text { Independent } \\
\text { Voters }\end{array}$ \\
\hline 1 & Green & Greenies & Green & $\begin{array}{l}\text { Protecting the } \\
\text { environment }\end{array}$ & Greenies \\
\hline 2 & Trees/forests & Minor party & Trees/forests & Climate & Green \\
\hline 3 & Climate & Green & $\begin{array}{l}\text { Protecting the } \\
\text { environment }\end{array}$ & Green & Trees/forests \\
\hline 4 & Greenies & Trees/forests & Climate & Trees/forests & Climate \\
\hline 5 & $\begin{array}{l}\text { Protecting the } \\
\text { environment }\end{array}$ & Climate & Greenies & Sustainability & Minor party \\
\hline 6 & Minor party & $\begin{array}{l}\text { Protecting the } \\
\text { environment }\end{array}$ & Minor party & $\begin{array}{l}\text { Supporting } \\
\text { same-sex } \\
\text { issues }\end{array}$ & $\begin{array}{l}\text { Protecting the } \\
\text { environment }\end{array}$ \\
\hline 7 & $\begin{array}{l}\text { Supporting } \\
\text { same-sex } \\
\text { issues }\end{array}$ & Unrealistic & Sustainability & Social justice & $\begin{array}{l}\text { Supporting } \\
\text { same-sex } \\
\text { issues }\end{array}$ \\
\hline 8 & Sustainability & Naïve & $\begin{array}{l}\text { Supporting } \\
\text { same-sex } \\
\text { issues }\end{array}$ & $\begin{array}{l}\text { Future- } \\
\text { focussed }\end{array}$ & Unrealistic \\
\hline 9 & Idealistic & Anti-business & Idealistic & Fair & Idealistic \\
\hline 10 & Alternative & $\begin{array}{l}\text { Supporting } \\
\text { same-sex } \\
\text { issues }\end{array}$ & Natural & Progressive & Naïve \\
\hline
\end{tabular}

Note: red = negative; black = neutral; green $=$ positive . 
Table 6. Top 10 Voter Associations - National Party of Australia (out of $15 ; \bar{x}=3.25$ )

\begin{tabular}{|c|c|c|c|c|c|}
\hline & Overall & $\begin{array}{l}\text { Coalition } \\
\text { Voters }\end{array}$ & Labor Voters & Green Voters & $\begin{array}{l}\text { Independent } \\
\text { Voters }\end{array}$ \\
\hline 1 & The Nationals & Rural & The Nationals & The Nationals & $\begin{array}{l}\text { A country } \\
\text { party }\end{array}$ \\
\hline 2 & Rural & The Nationals & $\begin{array}{l}\text { A country } \\
\text { party }\end{array}$ & Rural & Rural \\
\hline 3 & $\begin{array}{l}\text { A country } \\
\text { party }\end{array}$ & $\begin{array}{l}\text { Supports } \\
\text { farmers }\end{array}$ & Rural & $\begin{array}{l}\text { A country } \\
\text { party }\end{array}$ & The Nationals \\
\hline 4 & Coalition & $\begin{array}{l}\text { A country } \\
\text { party }\end{array}$ & Coalition & Conservative & Coalition \\
\hline 5 & $\begin{array}{l}\text { Supports } \\
\text { farmers }\end{array}$ & Coalition & $\begin{array}{l}\text { Junior partner } \\
\text { to the Liberals }\end{array}$ & Coalition & $\begin{array}{l}\text { Supports } \\
\text { farmers }\end{array}$ \\
\hline 6 & Conservative & Conservative & $\begin{array}{l}\text { Supports } \\
\text { farmers }\end{array}$ & Old-fashioned & Conservative \\
\hline 7 & $\begin{array}{l}\text { Junior partner } \\
\text { to the Liberals }\end{array}$ & $\begin{array}{l}\text { Junior partner } \\
\text { to the Liberals }\end{array}$ & Conservative & $\begin{array}{l}\text { Junior partner } \\
\text { to the Liberals }\end{array}$ & $\begin{array}{l}\text { Junior partner } \\
\text { to the Liberals }\end{array}$ \\
\hline 8 & Old-fashioned & Hard-working & Old-fashioned & $\begin{array}{l}\text { Supports } \\
\text { farmers }\end{array}$ & Old-fashioned \\
\hline 9 & 'The Nats' & 'The Nats' & Small & Small & Small \\
\hline 10 & Small & Honest & $\begin{array}{l}\text { Not well } \\
\text { known }\end{array}$ & $\begin{array}{l}\text { Not well } \\
\text { known }\end{array}$ & 'The Nats' \\
\hline
\end{tabular}

Note: red = negative; black = neutral; green $=$ positive . 
Figure 1. Multidimensional Scaling Plot: Liberal Party of Australia

\section{Liberal Party of Australia}

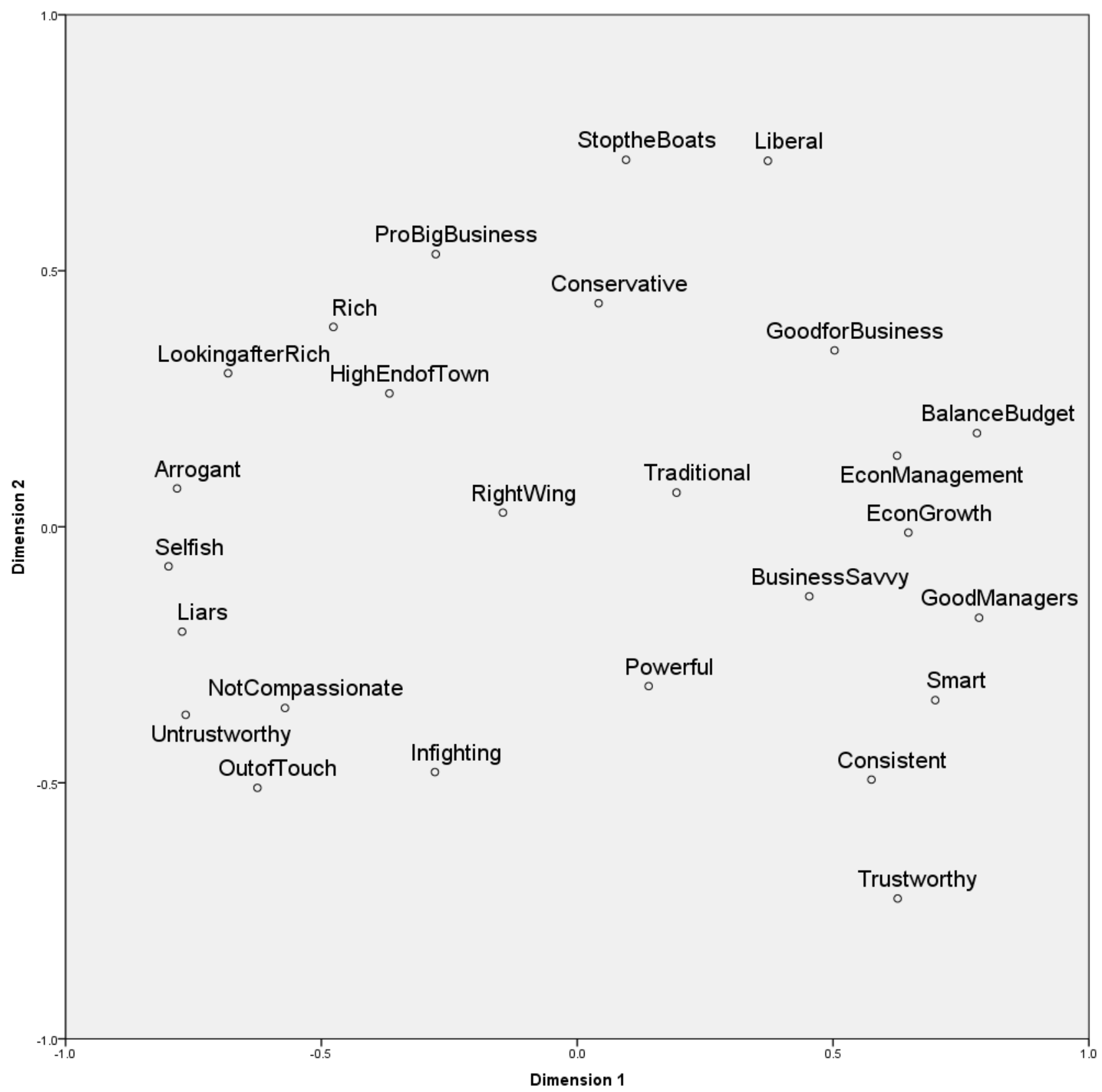


Figure 2. Multidimensional Scaling Plot: Australian Labor Party

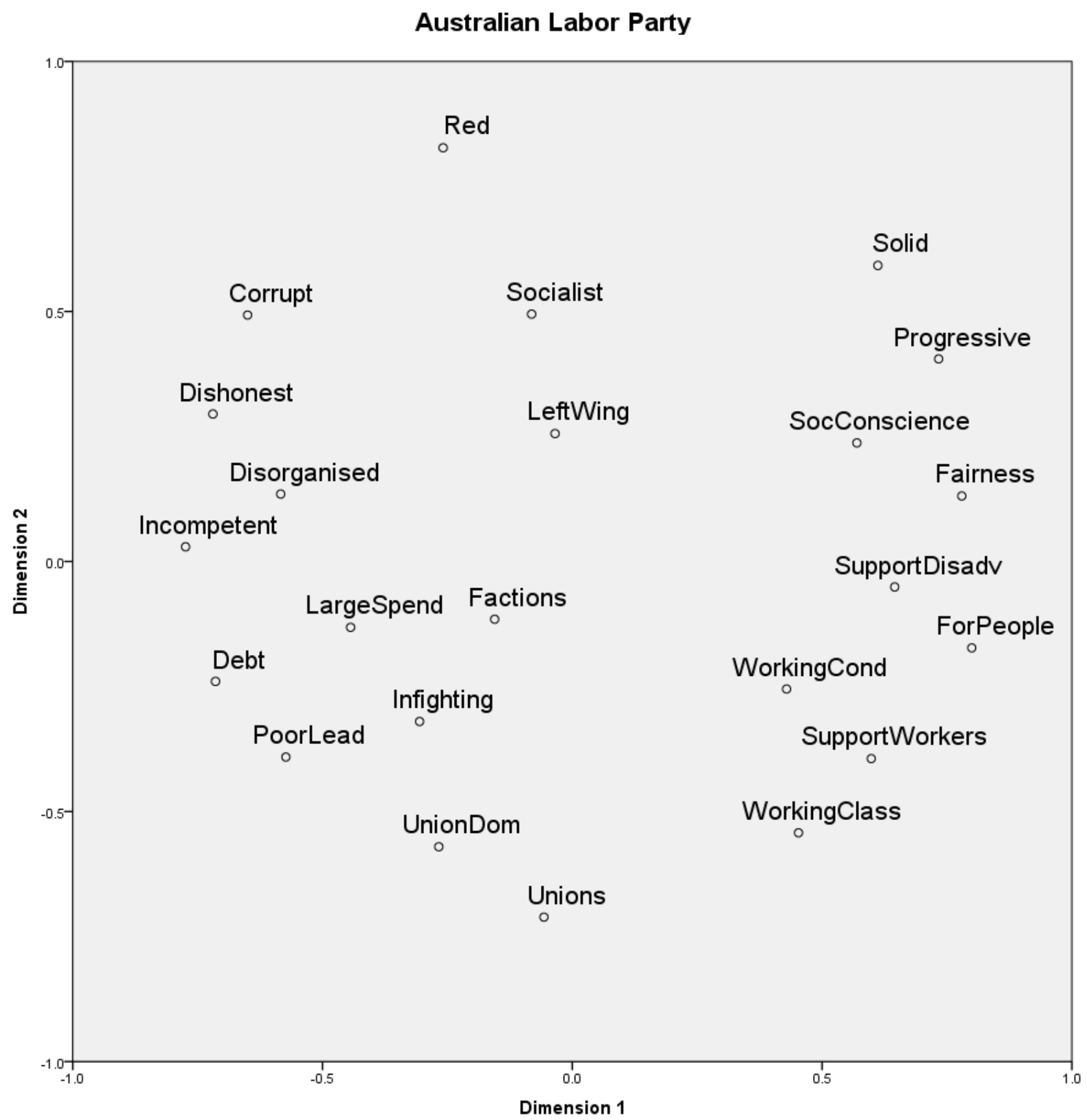


Figure 3. Multidimensional Scaling Plot: Australian Greens

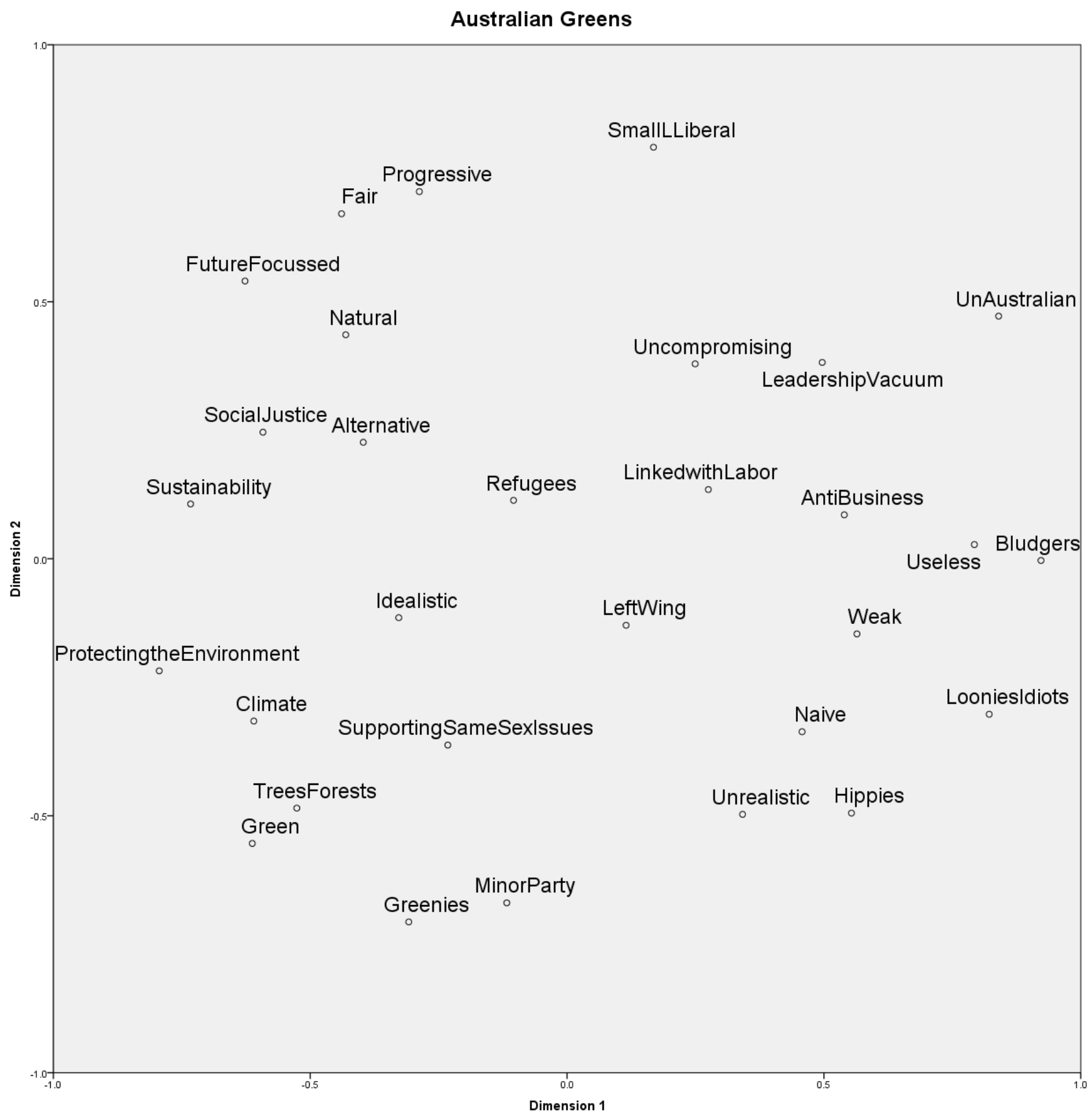


Figure 4. Multidimensional Scaling Plot: National Party of Australia

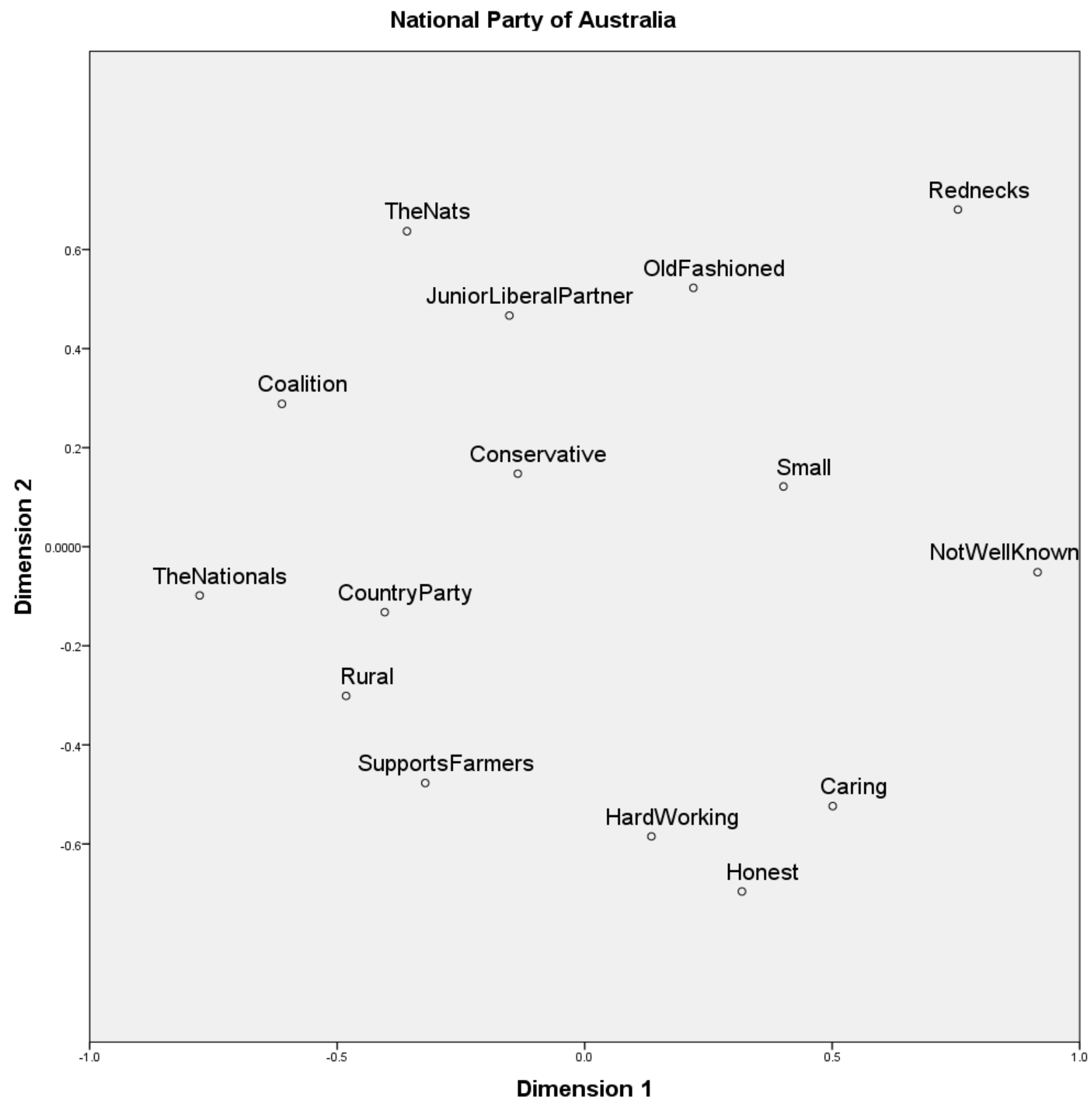

